\title{
Proceedings of the First Mosasaur Meeting - Introduction
}

\section{A.S. Schulp ${ }^{1,2,{ }^{\star}}$ \& J.W.M. Jagt ${ }^{1}$}

1 Natuurhistorisch Museum Maastricht, De Bosquetplein 6, NL-6211 KJ Maastricht, the Netherlands.

2 Faculty of Earth and Life Sciences, Vrije Universiteit Amsterdam.

* Corresponding author. Email: anne.schulp@maastricht.nl

During recent years, numerous new mosasaur taxa from around the world have been erected, which suggests there is currently much life in mosasaur studies. Yet, at every palaeontological meeting attended recently, we have come across only very few mosasaur workers. For that reason we felt the time was right to have a special session devoted solely to these wonderful marine reptiles.

Between 8 and 13 May 2004, the Natuurhistorisch Museum Maastricht hosted a special meeting on all aspects of mosasaur taxonomy, systematics and palaeobiogeography, plus biostratigraphy and taphonomy. From a historical viewpoint, the reason for choosing Maastricht is obvious: the lizards of the Maas River' were first discovered here around 1770, and formally described as Mosasaurus hoffmanni by Gideon Mantell in 1829 . In other words, Maastricht is the birthplace of mosasaurs.

The meeting, attended by over thirty participants from the Netherlands, Belgium, the United States, Canada, Japan, Bulgaria, Germany, Denmark and Sweden, covered a wide range of topics. The present volume combines a number of the papers presented during the meeting, and a few original contributions, mostly taxonomic in nature.

We wish to thank the following peers for reviewing manuscripts, and for contributing in many other ways to turn this meeting into a success: Nathalie Bardet, Gorden Bell Jr., Mike Caldwell, Mike Everhart, Donald Henderson, Robert Holmes, Louis Jacobs, Ulrich Kaplan, Johan Lindgren, Theagarten Lingham-Soliar, Marcin Machalski, Eric Mulder, Mike Polcyn, Marcus Ross, Jan Smit, Krister Smith, Dave Weishampel, and a handful of anonymous reviewers.
For assistance in organising the meeting, we extend our thanks to our colleagues Douwe de Graaf, Fokeline Dingemans, Paul Kisters, John Stroucken, Jos Lardinoye, Chris Franssen, Pierre Vandewall and George Steijn. Many thanks to Dirk Cornelissen and Louis Verding for arranging a special display at the Natuurhistorisch Museum Maastricht during the meeting, showing the mosasaur material in their own collections. We also greatly appreciate Jan Smit, Hubert Vonhof and Rudi Dortangs for their contribution to the excursion to the Geulhemmerberg KT-section and to the ENCI-Maastricht B.V. quarry, the type section of the Maastrichtian stage. Many thanks to Bert Sliggers and John de Vos (Teylers Museum) for their hospitality. 